\title{
Assessing the Role of Digital Finance on Shadow Economy and Financial Instability: An Empirical Analysis of Selected South Asian Countries
}

\author{
Aamir Aijaz Syed ${ }^{1}\left(\mathbb{D}\right.$, Farhan Ahmed ${ }^{2}\left(\mathbb{D}\right.$, Muhammad Abdul Kamal ${ }^{3} \mathbb{D}$ and Juan E. Trinidad Segovia ${ }^{4, *}$ \\ 1 Institute of Management Commerce and Economics, Shri Ramswaroop Memorial University, \\ Lucknow 226016, India; amiraija.imce@srmu.ac.in \\ 2 Department of Economics and Management Sciences, NED University of Engineering \& Technology, \\ Karachi City 75270, Pakistan; fahmed@neduet.edu.pk \\ 3 Department of Economics, Abdul Wali Khan University, Mardan 23200, Pakistan; kamal@awkum.edu.pk \\ 4 Department of Business and Economics, Universidad de Almeria, 04120 Almería, Spain \\ * Correspondence: jetrini@ual.es
}

check for updates

Citation: Syed, A.A.; Ahmed, F.; Kamal, M.A.; Trinidad Segovia, J.E. Assessing the Role of Digital Finance on Shadow Economy and Financial Instability: An Empirical Analysis of Selected South Asian Countries. Mathematics 2021, 9, 3018. https:/ / doi.org/10.3390/math9233018

Academic Editor: Palle E.

T. Jorgensen

Received: 25 October 2021

Accepted: 23 November 2021

Published: 25 November 2021

Publisher's Note: MDPI stays neutral with regard to jurisdictional claims in published maps and institutional affiliations.

Copyright: (c) 2021 by the authors. Licensee MDPI, Basel, Switzerland. This article is an open access article distributed under the terms and conditions of the Creative Commons Attribution (CC BY) license (https:// creativecommons.org/licenses/by/ $4.0 /)$.

\begin{abstract}
The advancement in fintech technological development in emerging countries has accelerated the role of digital finance in economic development. Digital finance assists in financial inclusion; however, it may also increase the chances of financial instability due to systematic risks. Emerging countries are also in the clutches of shadow economic growth, which reduces taxable income revenue and creates pressure on financial inclusion prospects. The current study attempts to measure the impact of digital finance on the shadow economic growth and financial stability among the selected South Asian emerging countries. We have used the CUP-FM and CUP-BC estimation methods to measure the above relationship on two model frameworks from 2004 to 2018, with the former measuring the influence of digital finance on the shadow economy and the latter examining the relationship between digital finance and financial stability. In addition, the second-generation unit root test, and the Westerlund cointegration analysis are also employed to confirm the stationarity and cointegration among the variables. The result of the Westerlund's cointegration confirms a long cointegration between the explanatory and outcome variables. Furthermore, the long-run estimation results conclude that an increase in digital finance helps in reducing the growth of the shadow economy among the selected sample countries. However, it also increases the likelihood of systematic risks and increases financial instability. The study also reveals that the control variables like unemployment and industrial productivity also have a significant influence on financial stability and the shadow economy. The findings will assist readers in comprehending how digital finance influences the shadow economy and promotes financial inclusion and stability in emerging nations.
\end{abstract}

Keywords: fintech; digital finance; shadow economy; financial inclusion; CUP-FM; CUP-BC

\section{Introduction}

Digital finance involves the unification of financial services and digital technologies. The advancement in big data analysis, artificial intelligence, and information technology has made a remarkable contribution toward digitalization [1]. Digitalization in finance means the increased use of digital technologies in the working and product development of the banking and finance sector. Digital finance provides individuals and firms with a wide array of sustainable financial services, for instance, digital services such as online payments, credit, investments, remittances, and savings. Individuals and firms use these digital services through digital channels of the banks like mobile app, automatic teller machines, point of sales terminals, etc. New fintech services are also included apart from the above-established services in digital payments, such as cryptocurrency, peer-to-peer applications, and digital ledger technologies [2]. During the last three years, according to the report of the International Monetary fund, there is an unprecedented increase in digital 
payments, digital remittances, and digital lending in emerging and developing countries. In emerging and developing countries, digital payment services rose from $\$ 1.2$ trillion in 2017 to $\$ 1.5$ trillion in 2019. Similarly, mobile payments have also increased by 50\% in 2019 compared to the previous year. In emerging and developing countries, not only has the value of digital and mobile payment increased, but the number of users has also increased, for instance, the mobile payment users have increased from 3.3 billion in 2017 to 4 billion in 2019, which is approximately $64 \%$ of the population [3]. Thus, it can be inferred from the above data that technological advancement in financial services leads to financial inclusion.

Financial inclusion refers to the ability of financial services to reach out to a distant population. The technological spillover theory states that financial inclusion results from reaching out to people through the internet and fintech technologies. Financial inclusion is also one of the prime tenets of the sustainable development goal of 2030 [4]. Therefore, most of the developing countries are trying to convert their non-banking populations into banking populations. Developing countries are resorting to excessive use of the fintech revolution and digital finance to increase financial inclusion. However, most developing countries still have insufficient infrastructure and available resources to expedite the process of financial inclusion [1]. For instance, as per the report of the McKinsey Global Institute, $2021,53 \%$ of the population is financially excluded in the emerging countries of South Asia whereas this is only 23\% in China, 48\% in Latin America, and 39\% in Eastern Europe and Central Asia. In addition, the report also concludes that the share of emerging countries in digital payments is also low compared to developed countries, for example, the share of digital payments in emerging countries such as India, Pakistan, Indonesia, and Bangladesh is less than 1\% compared to 77\% in Australia, 55\% in the United Kingdom, $49 \%$ in the United States, $33 \%$ in Germany, etc.

The lack of adequate infrastructure and unavailability of resources creates another problem, that of the shadow economy, among developing countries. The shadow economy refers to the growth of the parallel economy or the informal economy. It includes not only illegal business transactions but also legal activities which are not under countries' formal tax brackets. The informal economy reduces the taxable income of the country and hampers economic development in the long run [5]. The proportion held by the shadow economy among the developing countries is more than 30\% [6]. The lack of access to banking services is the major determinant of the shadow economy. Globally, around 70\% of the population does not have access to banking services for their financial needs [7]. In developing countries, $50 \%$ of the population has no access to financial services. However, in this strenuous situation, the growth in digital finance is the only hope of increasing financial inclusion and restricting the growth of shadow economies among developing countries. Although digital finance may help control the shadow economy through financial inclusion, some recent studies have emphasized that digital finance may promote financial sector instability through systematic risk [8]. The excessive use of digital payments and digital platforms may increase unethical activities and create financial sector instability.

Based on these technological spillover effects, this study investigates the impact of digital finance on the shadow economy and financial stability among the panel of selected South Asian countries. The reason for including South Asian countries is justified in the following ways. In South Asia, there are eight countries, and of these eight countries three, namely India, Bangladesh, and Pakistan represent the fastest emerging markets of South Asia with a large population and extensive market potential. Besides, being emerging markets in terms of potential demand, the progress of these countries in terms of financial inclusion is comparatively slower. In the above four countries, the access to financial services is around eightfold lower than in the high-income group countries. Apart from this, $60 \%$ of adults in South Asian countries lack access to formal financial services [9]. The proportion of the shadow economy in the South Asian countries is also higher compared to other emerging economies of the world. However, due to the sustainable development goal of the recent past, these countries are striving hard to increase their financial inclusion targets. Over the years, the inhouse technological development and knowledge sharing 
from developed countries have improved the platform for digital finance in South Asian countries. For instance, in India, which represents more than $80 \%$ GDP of South Asia, the growth in digital finance is manifold. According to the report of ACI worldwide, digital transactions are expected to grow by $71.7 \%$ in India by 2025. Similarly, the World bank report advocated a bullish view on the Pakistani cashless economy, estimating it at $\$ 36$ billion, which will create a boost of 7\% in Pakistan's GDP. The untapped financial market, high level of shadow economy, and ongoing transition in digital finance further motivate us to investigate the above relationship in the context of South Asian countries.

The current study contributes to the extant literature on digital finance in the following ways. First, this study investigates the impact of digital finance on the shadow economy among South Asian countries, which as per the author's knowledge has not been explored in previous studies conducted on digital finance. Second, this study also examines the relationship between digital finance and financial stability, which also adds a new paradigm in the context of the consequences of digital finance among emerging countries. The sustainability goal of 2030 promotes the usage of fintech technologies and digital finance for sustainable economic development. Therefore, evaluating its consequences on financial stability will add significantly to the literature on digital finance. Third, this study uses a continuously updated fully modified, and biased corrected model, which provides robust results in the presence of cross-sectional dependency (CSD), heteroskedasticity, autocorrelation, and fractional integration. The CUP-FM and CUP-BC estimation technique are also appropriate techniques for small sample size data. In addition, we have also empirically investigated the issue of CSD by employing a second-generation unit root test and Westerlund cointegration analysis, which provide better estimates in the presence of CSD. Thus, these methods also contribute toward the novelty of our approach, as these methods are not used in earlier studies on digital finance. Some of the countries included in the study are among the most populated countries, with transition market structures. These countries also have a high proportion of shadow economy compared to other countries of the world. Besides, these countries are also taking drastic measures to improve financial inclusion through fintech technologies and digital finance. Therefore, the sample selection also contributes to the novelty of the study. The current study also includes two prominent proxies to measure the growth of digital finance, which have not been comprehensively discussed in previous studies, thus adding to the literature. Therefore, the findings will be helpful for other emerging countries to understand and devise appropriate policies for the expansion of fintech technologies. Furthermore, to estimate the above relationship, the following hypothesis is formulated:

Hypothesis 1. Digital finance has a significant negative impact on the growth of the shadow economy.

Hypothesis 2. Digital finance has a significant positive impact on financial sector stability.

The paper further proceeds as follows; Section 2 covers a literature review and theoretical framework; Section 3 focuses on methodology and variable description; Section 4 covers data analysis, and Section 5 includes the concluding remarks and discussion.

\section{Theoretical Underpinning and Empirical Literature}

\subsection{Theoretical and Conceptual Framework}

The technological spill-over theory states that digital finance can help the finance sector in three ways. Technological spill-over increases financial inclusion, provides technically equipped employees, and increases financial disintermediation. Through the squid effect, digital finance transforms traditional financial institutions by improving technology, reducing cost, expanding financial sector outreach activities, and improving financial system efficiency [10]. The theoretical underpinning for the relationship between digital finance and financial inclusion is based on the premise that a large proportion of the ex- 
cluded population owns (or has) a mobile phone. The provision of financial services via mobile phones and related devices can improve access to finance for the excluded population [11]. Further, [6] concluded that financial outreach activities and economic growth help in reducing the shadow economy. Hence, based on these conceptual frameworks, the impact of digital finance on the shadow economy and financial instability can be justified.

\subsection{Review of the Empirical Literature}

The rapid advancement in digital finance has attracted the attention of various researchers. Being a hot topic, scholars have examined the impact of digital finance on the financial sector and economic growth. The subsequent section highlights the details of some of the recent literature on digital finance.

\subsubsection{Digital Finance, Financial Inclusion, and Shadow Economy}

In recent studies, digital finance is defined as the combination of digital technologies and financial services [1]. Previous studies have outlined various benefits of using digital finance. For example, digital finance helps in promoting financial intermediation and financial inclusion, reduces poverty, and helps in sustainable development $[10,12,13]$. In addition, the use of mobile phones and internet services for online payment in developing countries also promotes financial sector literacy and increases financial inclusion [14]. Srivastava [15] advocated that shifting from the traditional model of financial transaction to digital finance helps in reducing the transaction cost of financial services and in the growth of the financial sector of emerging countries like India and China. Similarly, the development in fintech technologies also has a positive impact on the banking sector, and promotes financial liberalization in emerging countries [16]. Witnessing the positive impact of digital finance on the banking and financial sector, various researchers have also examined its impact on financial inclusion. Evans [17] investigated the relationship of digital finance with financial inclusion in Africa. The author confirmed that, due to the excessive use of mobile and internet services caused by technological development, there is a considerable expansion in the degree of financial inclusion in the African region.

Various scholars have iterated that ICT-enabled technologies have significantly contributed toward the development of low-cost financial services. ICT-enabled technologies such as mobile payments, mobile wallets, online payment mechanisms and branchless banking have improved the level of financial inclusion and financial outreach $[18,19]$. Over the last few years, due to the excessive investment in research and development activities in emerging countries, there has been a considerable improvement in the innovation of low-cost technologies. These low-cost technological innovations have enhanced the market for mobile phones and internet services. The availability of mobile phones and other digital gadgets has further enhanced digital payments in emerging countries [20]. These technological transitions have transformed traditional financial services into digital financial services. For example, cryptocurrency is substituted for paper currency, and card transactions are substituted for cash transactions [21]. This digital transformation has also helped in loan recovery and loan disbursement by artificial tracking mechanisms. However, in some developing countries, there is still a part of the population that is not under the scanner of this digital transformation, and still relies on the informal economy for its financial needs. To evade the tax burden and avoid the process of documentation and disclosure of financial services, these untapped populations rely on the informal economy, which is also known as the shadow economy [22].

A vast body of literature has concluded that the shadow economy has a detrimental impact on a country's economic growth [23-25]. The shadow economy reduces taxable income revenue, and it also hampers the process of financial inclusion [26]. Previous studies have projected that the political environment plays a crucial role in the rise of the shadow economy [27]. An unstable political environment promotes unemployment, low productivity, and hence a rise in the informal economy. In addition, the political stability index of some of the emerging countries is low compared to the developed 
countries. Hence, through its mediation role, it hampers the productivity and stability of various industries. For instance, Zhau and Tewari [28] projected that high instability and corruption promote the shadow economy which eventually increases banking risk and instability in emerging countries. However, some studies have concluded that the shadow economy creates employment opportunities for the unemployed and helps in controlling poverty [24]. A strand of the literature also concluded that due to the presence of the shadow or informal economy, the impact of the global financial recession was less severe on developing countries compared to the developed countries [29]. Although there are some positives for the shadow economy based on previous findings and given a larger picture, the negative consequences of the shadow economy are more detrimental than the positive aspects. Over the years, developing countries have resorted to restricting the growth of the shadow economy through financial outreach activities [30]. Additionally, the Global Financial Stability Report of the International Monetary Fund [31] also states that developing countries are witnessing tremendous growth in their banking sector, thus implying a reduction in the shadow economy. Earlier discussion in previous studies concluded that digital finance helps in promoting financial inclusion, and as financial inclusion also helps in controlling the shadow economy, thus some relationship between shadow economy and digital finance can also be established. As per the review, no study has examined the relationship between digital finance and the shadow economy. Therefore, to contribute to filling this literature void, we have examined the above relationship in the context of selected South Asian countries. The next section of the study focuses on the extant literature on digital finance and financial sector instability.

\subsubsection{Digital Finance and Financial Instability}

Globalization in the financial sector due to technological advancement has not only generated a positive impact on the financial sector's development and economic growth, but it has also generated negative consequences. The evolution of integrated financial services without border restrictions has created financial sector instability [32]. Globalization and interconnectivity help in transferring financial sector instability from one country to another. One the on hand, digital finance that helps in promoting financial sector development also creates chances for systematic risks. Various factors cause systematic or business risks such as institutional linkage, financial market connectivity, macroeconomic conditions, and the size of the financial sector [33]. Ozili [12] concluded that, although digital finance helps in expediting the process of financial inclusion, it also contains some risks. For instance, easy availability of credit helps in increasing nonperforming loans, and excessive use of fintech technologies increases digital risk such as theft of data, disruption in payment systems, etc. [34]. The lack of timely and stringent regulatory mechanisms also aggravates systematic risk, especially in developing countries [35]. Furthermore, García and José [36] noted that systematic risk increases with new financial outreach activities, as these activities are not so adequately regulated. Similarly, Khan [37] highlighted that institutions that adopt the business correspondent framework of financial inclusion are more exposed to strategic and compliance risks.

In addition to the negative apprehensions of digital finance growth, some authors have also highlighted the positive sides of fintech development on financial sector stability. For instance, some have concluded that expansion in digital financial services helps in reducing operational costs. It enhances the speed of financial transactions and assists in creating an environment for stable and secure transactions. It also ensures proper tracking and monitoring of financial transactions [38]. The expansion in digital financial services also increases the share of the unbanked population in formal banking, and thus diversifies market risks and promotes financial sector stability [39].

Based on the above literature review, we can conclude that digital finance may promote financial instability because of the transmission properties and interconnectivity among the countries. However, some studies conclude that digital finance reduces financial sector instability and systematic risk by providing better risk management techniques [40,41]. 
In continuation, based on the above literature review, we can also conclude that there is no specific study that estimates the role of digital growth on the unbanked population. Therefore, to bridge this literature gap, we have examined the above relationship for South Asian countries.

\section{Data, Variables and Empirical Methodology}

\subsection{Data and Variables}

We have included the following proxies to examine the relationship between digital finance, shadow economy, and financial stability. Mobile money transaction percentage of GDP and number of ATMs per 100,000 population is used as a proxy to measure digital finance. The Mobile money transaction and ATMs per 100,000 population is the most commonly used proxy to measure digital finance, as this highlights the penetration of internet and mobile services in an economy [42]. We have used nonperforming loan (NPL) percentage of GDP and bank credit to deposit ratio (BCDR) as a proxy to measure financial stability. The following proxies' variables are included because a high ratio of BCDR and NPLs denotes higher credit and default risk, which may lead to financial sector instability. Various previous studies have used the same proxy for financial sector instability [43]. In addition, to measure the impact of digital finance on the informal economy, we have used the proxy shadow economy as a percentage of GDP, following the work of Zhou and Tewari [28]. Besides this, we have also included certain control variables like gross domestic product, unemployment, industrial productivity, and foreign direct investments. Industrial productivity and foreign direct investments are included in this study, as these variables contribute extensively to economic and financial sector development. Hence, evaluating their impact on financial instability and the shadow economy will contribute to the extant literature. The annual data of three South Asian countries from 2004-2018 are included for empirical analysis. We have included the above sampled countries and timeframe to maintain consistency in the data frequency, because the data for most of the explanatory variables is not available before 2004 and beyond 2018, especially for shadow economy and digital finance proxies. Furthermore, annual data is included to avoid under representation. Table 1 shows the detail of variables, data sources, and sampled countries.

Table 1. Variables' description and data sources.

\begin{tabular}{cc}
\hline Variable & Source \\
\hline $\begin{array}{c}\text { Digital payment proxy mobile money transaction } \\
\text { percentage of GDP }\end{array}$ & Financial Access Survey \\
\hline $\begin{array}{c}\text { Number of ATM per 100,000 adults } \\
\text { Financial Instability proxy (NPLs and Bank } \\
\text { credit-deposit ratio) }\end{array}$ & Financial Access Survey \\
\hline Shadow economy (SE) & IMF financial statistic database \\
\hline Gross Domestic Product (GDP) & Schneider, F., et al. Working paper 2018 \\
\hline Unemployment (Un) & World Development indicators \\
\hline Foreign Direct Investment (FDI) & World Development indicators \\
\hline Industrial Productivity (IIP) & World Development indicators \\
\hline Sample South Asian Countries: India, Pakistan, and Bangladesh
\end{tabular}

\subsection{Model Specification and Estimation Method}

To investigate the long-term impact of digital finance on the shadow economy and financial instability, we have used panel cointegration analysis along with CUP-FM and CUP-BC estimation techniques. We have used a continuously updated fully modified and bias-corrected model for long-run estimation as our dataset is relatively long, and it also has few cross-sections. The countries which we have selected for the empirical analysis are 
interlinked, therefore there are high chances of cross-sectional dependence (CD) among the variables. Hence, we have also used the cross-sectional dependence test, attached in Table 2. Previous studies have highlighted that the presence of CD hampers the results of traditional unit root tests such as the PP test and ADF test [44]. Therefore, to provide robust results, we have used the CADF and CIPS unit root test. These tests provide better estimates in the presence of cross-sectional dependence and heterogeneity in the dataset. The equation used in the CIPS test is summarized below:

$$
\Delta y_{i t}=c_{i}+p_{i} y_{i t-1}+d_{i} \bar{y}_{t-1}+\sum_{j=0}^{n} e_{i j} \Delta \bar{y}_{i t-1}+\sum_{j=0}^{n} \beta_{i j} \Delta \bar{y}_{i t-1}+\mu_{i t}
$$

where $n$ is the lag, $\mu_{i t}$ the error term, $y_{i t}$ the analyzed variable, $\bar{y}$ the observation average, $c$ the individual intercept and $t$ the time. Under the CIPS unit root test, null hypothesis assumes data which is non-stationary against the alternative hypothesis, or otherwise.

Table 2. Cross sectional Dependency test.

\begin{tabular}{|c|c|c|c|c|c|c|c|c|c|}
\hline & NPL & SE & BCDR & MMT & ATM & IIP & UN & FDI & GDP \\
\hline \multirow{2}{*}{$\begin{array}{c}\text { Breusch Pagan } \\
\text { LM Test }\end{array}$} & 43.23 * & $65.71 *$ & 41.21 * & 23.13 * & 121.32 * & $65.32 * *$ & 71.23 * & $34.21^{* *}$ & 17.34 * \\
\hline & 0.0000 & 0.0000 & 0.0000 & 0.0000 & 0.0000 & 0.0000 & 0.0000 & 0.0000 & 0.0000 \\
\hline \multirow{2}{*}{$\begin{array}{c}\text { Pesaran Scaled } \\
\text { LM Test }\end{array}$} & 12.12 * & $9.34 * *$ & $8.12 *$ & $18.32 *$ & $5.13 *$ & $7.12 *$ & 11.09 * & $17.32 * *$ & 4.12 * \\
\hline & 0.0000 & 0.0000 & 0.0000 & 0.0000 & 0.0000 & 0.0000 & 0.0000 & 0.0000 & 0.0000 \\
\hline
\end{tabular}

Note: ${ }^{*}{ }^{* *} 1$ and $5 \%$ level of significance.

Proceeding further, we estimated the long-run cointegration between the variables. To investigate the long-run cointegration, we have employed the Westerlund [45] panel cointegration technique. This cointegration technique is a combination of two pooled and two groups' mean statistics and provides robust estimates in the presence of cross-sectional dependency by using the bootstrap technique [46]. The structure used in the Westerlund panel cointegration is summarized below.

$$
\Delta y_{i t}=\delta_{i} k_{t}+\alpha_{i}\left(y_{i, t-1}-\beta \prime_{i} x_{i, t-1}\right)+\sum_{j=1}^{r_{i}} \alpha_{i j} \Delta y_{i, t-j}+\sum_{-s_{i}}^{r_{i}} y_{i j} \Delta x_{i, t-j}+e_{i t}
$$

Note: $k_{t}$ represents deterministic components, $r_{i}$ and $s_{i}$ are the lead and lag orders, $e$ is the error term, $G_{t}, G_{\alpha}$ are the group-mean test statistics and $P_{t}, P_{\alpha}$ are the two panel test statistics.

$$
\begin{gathered}
G_{t}=\frac{1}{N} \sum_{i=1}^{N} \frac{\hat{\alpha_{t}}}{S E_{\hat{\alpha_{t}}}} \\
G_{\alpha}=\frac{1}{N} \sum_{i=1}^{N} \frac{T \hat{\alpha_{t}}}{\hat{\alpha_{t}}(1)} \\
P_{t}=\frac{\hat{\alpha_{t}}}{S E_{\hat{\alpha_{t}}}} \\
P_{\alpha}=T \hat{\alpha}
\end{gathered}
$$

After confirming the presence of cointegration among the variables, we have further proceeded by checking the long-run relationship, and its magnitude, between the dependent and independent variables. As already discussed, we have used CUP-FM and CUP-BC estimation techniques to estimate the long-run relationship between the variables. Previous studies have concluded that there are various models for estimating long-run relationships; however, each method has its limitation. For instance, GMM is considered a robust technique to counter endogeneity and serial correlation, but it is not a reliable technique when the time dimension is more than cross-sectional [47]. Similarly, FMOLS and DOLS, which are considered efficient techniques to tackle endogeneity and serial correlation issues, are not appropriate to tackle cross-sectional dependence. In recent studies, 
DSUR is commonly used to counter the problem of cross-sectional dependence, but this technique cannot also deal with endogeneity and residual correlation [48].

In short, we can conclude that although there are various models for long-run estimation, each model has its limitations. Therefore, to avoid all the above problems, and provide robust estimates, we have employed CUP-FM and CUP-BC estimation techniques. The CUP-FM technique is appropriate to tackle the problem of residual correlation, crosssectional dependence, endogeneity, and heteroskedasticity. According to Ahmed et al. [49], the CUP-FM estimation technique is also suitable for small sample size datasets. Therefore, considering the positive side, we have used the CUP-FM estimation model proposed by Bai et al. [50] in our analysis. To further check the robustness of our empirical findings, we have used the CUP-BC estimation technique proposed by Bai et al. [50], which is an extension of the CUP-FM estimation technique and provides similar benefits. The equation used for CUP-FM and CUP-BC is as follows:

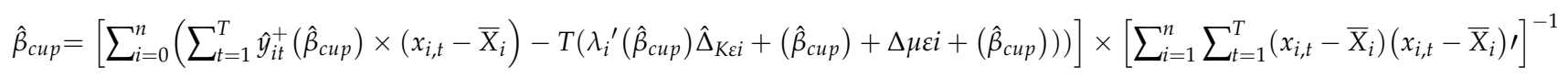

where $\hat{\Delta}_{K \varepsilon i}$ are $\hat{\Delta}_{\mu \varepsilon i}$ estimated one side covariance, and $\hat{y}_{i t}^{+}=y_{i t}-\left(\hat{\lambda}_{l}^{\prime} \hat{\Omega}_{K \varepsilon i}+\hat{\Omega}_{\mu \varepsilon i}\right) \hat{\Omega}_{\varepsilon i}^{-1} \Delta X_{i t}$ and $\hat{\Omega}_{K \varepsilon i}$ and $\hat{\Omega}_{\mu \varepsilon i}$ are long run covariance matrices. Besides, the above equation is the basic framework used to estimate the relationship between digital finance, shadow economy, and financial stability as summarized below:

Model 1: Impact of Digital finance on the shadow economy.

$$
(L n S E)_{i t}=\delta_{0}+\delta_{1} L n M M T_{i t}+\delta_{2} L n G D P_{i t}+\delta_{3} L n F D I_{i t}+\delta_{4} L n I I P_{i t}+\delta_{5} \operatorname{LnUn_{it}}+\delta_{6} \operatorname{LnATM} M_{i t}+\mu_{i t}
$$

Model 2: Impact of Digital finance on financial instability.

$$
\begin{aligned}
& (\operatorname{LnNPL})_{i t}=\delta_{0}+\delta_{1} \operatorname{LnMMT}_{i t}+\delta_{2} \operatorname{LnGDP_{it}}+\delta_{3} \operatorname{LnFDI_{it}}+\delta_{4} \operatorname{LnIIP_{it}}+\delta_{5} \operatorname{LnUn_{it}}+\delta_{6} \operatorname{LnATM_{it}}+\mu_{i t} \\
& (\operatorname{LnBCDR})_{i t}=\delta_{0}+\delta_{1} L n M M T_{i t}+\delta_{2} L n G D P_{i t}+\delta_{3} L n F D I_{i t}+\delta_{4} L n I I P_{i t}+\delta_{5} L n U n_{i t}+\delta_{6} L n A T M_{i t}+\mu_{i t}
\end{aligned}
$$

In the above model SE refers to the shadow economy, NPL represents nonperforming loans, BCDR represents bank credit to deposit ratio, MMT refers to mobile money transactions as percentage of GDP, GDP represents the gross domestic product, IIP represents industrial productivity, $\mathrm{UN}$ refers to unemployment, FDI refers to foreign direct investments, ATM refers to the number of ATM per 100,000 adults and $\mu_{i t}$ shows error terms. All the above variables are in their natural logarithm form. The descriptive statistics for the variables are shown in Table 3.

Table 3. Descriptive Statistics.

\begin{tabular}{ccccccc}
\hline & Mean & Median & Maximum & Minimum & $\begin{array}{c}\text { St. } \\
\text { Deviation }\end{array}$ & $\begin{array}{c}\text { Probability } \\
\text { Value }\end{array}$ \\
\hline NPL & 9.27 & 8.94 & 17.5 & 2.21 & 4.32 & 0.0012 \\
\hline SE & 30.21 & 31.18 & 36.8 & 17.89 & 2.93 & 0.0300 \\
\hline BCDR & 72.82 & 74.84 & 93.3 & 48 & 12.33 & 0.0100 \\
\hline MMT & 4.95 & 3.02 & 17.09 & 0.0051 & 5.431 & 0.0019 \\
\hline ATM & 7.07 & 5.28 & 21.99 & 0.12 & 6.121 & 0.0000 \\
\hline IIP & 111.30 & 104.09 & 219.55 & 59.67 & 33.99 & 0.0500 \\
\hline UN & 4.60 & 4.35 & 7.70 & 3.05 & 1.06 & 0.0200 \\
\hline FDI & 1.40 & 1.17 & 3.66 & 0.38 & 0.791 & 0.0000 \\
\hline GDP & 6.05 & 6.15 & 10.26 & 0.99 & 2.051 & 0.0078 \\
\hline
\end{tabular}

\section{Empirical Results \& Discussion}

Descriptive statistics show that most of the variables have a high mean score in the selected South Asian countries compared to the other developed or emerging countries. For 
instance, the average shadow economy is $30.21 \%$ of GDP in the selected countries, whereas the average shadow economy in developed countries is around $7 \%$. The nonperforming loans average in the sample countries is $9.27 \%$; on the contrary, the average NPL in other developed countries is less than $4 \%$. Similarly, the unemployment rate is also high in the sampled countries. When we see the progress of digitalization, the mean is low in the sampled countries compared to global standards. For instance, the number of ATMs per 100,000 population in India, Pakistan, and Bangladesh is 22.12, 10.23, and 8.09; contrary to this, the number of ATMs per 100,000 population in other developed countries is much higher than in our sampled countries. For example, in China, it is 95.09, and in Russia, it is 165.09. The result is also the same in the case of mobile money transaction as percentage of GDP, which is also low compared to other global emerging countries such as China. Based on these descriptive facts and statistics, we can conclude that studying the relationship between digitalization, shadow economy, and financial stability in the selected region will contribute significantly to the extant literature.

Moving further into the empirical investigation, first we have examined the issue of cross-sectional dependence among the sample data. The result of the Breusch Pagan and Pesaran LM test attached in Table 2 confirms the presence of CD among the regressors, as the $p$-value is less than $5 \%$. This indicates that disturbance/shock in one country causes a spill-over effect in another country. The results of the cross-sectional dependency test further strengthen our empirical analysis for using the second-generation unit root test. As discussed earlier, the second-generation unit root test provides better estimates in the presence of cross-sectional dependence.

The result of the CIPS and CADF second-generation unit root test reported in Table 4 confirms that some variables are non-stationary at the levels. However, when we analyzed the data at the first difference, the results affirm the presence of no unit root, and all the variables are integrated at the first difference I(1). Based on these satisfactory outcomes of the unit root test, we moved to the cointegration analysis.

Table 4. Unit root Test.

\begin{tabular}{ccccc}
\hline & \multicolumn{2}{c}{ CIPS } & \multicolumn{2}{c}{ CADF } \\
\cline { 2 - 5 } & Level & First Difference & Level & First Difference \\
\hline NPL & -2.124 & $-3.595^{*}$ & -3.521 & $-4.091^{*}$ \\
\hline SE & -2.812 & $-3.194^{* *}$ & -2.562 & $-3.132^{*}$ \\
\hline BCDR & -2.437 & $-4.609^{*}$ & -3.012 & $-4.752^{* *}$ \\
\hline MMT & -3.791 & $-3.991^{*}$ & -2.912 & $-3.131^{*}$ \\
\hline ATM & -0.842 & $-2.662^{*}$ & -2.563 & $-2.132^{*}$ \\
\hline IIP & -2.531 & $-3.812^{* *}$ & -3.662 & $-3.085^{*}$ \\
\hline UN & -1.994 & $-2.562^{*}$ & -2.019 & $-3.121^{*}$ \\
\hline FDI & -0.812 & $-1.345^{*}$ & -3.131 & $-3.998^{* *}$ \\
\hline GDP & -2.398 & $-3.556^{*}$ & -2.442 & $-3.131^{*}$ \\
\hline
\end{tabular}

Note: ${ }^{*}, * *$ at $1 \%$ and $5 \%$ level of significance.

In the cointegration estimation, we have used the Westerlund panel cointegration analysis. The result of the Westerlund cointegration in Table 5. confirms long-run cointegration among the regressors. The $G_{t}, G_{a}, P_{t}, P_{a}$ values are significant at 1 and $5 \%$ levels of significance. The result is confirmed based on the $p$-values calculated using the bootstrap mechanism. 
Table 5. Westerlund Cointegration analysis.

\begin{tabular}{|c|c|c|c|c|}
\hline Model & Statistic & Value & $z$-Value & $p$-Value \\
\hline \multirow{4}{*}{ (1) } & $G_{t}$ & -4.101 & -3.109 & 0.0000 * \\
\hline & $G_{a}$ & -6.110 & -4.010 & 0.0000 * \\
\hline & $P_{t}$ & -4.120 & -4.602 & $0.0000^{* *}$ \\
\hline & $P_{a}$ & -4.563 & 5.209 & 0.0000 * \\
\hline \multirow{4}{*}{ (2) } & $G_{t}$ & -6.109 & -6.109 & 0.0001 * \\
\hline & $G_{a}$ & -9.113 & 3.098 & 0.0000 * \\
\hline & $P_{t}$ & -9.211 & -3.198 & $0.0002 *$ \\
\hline & $P_{a}$ & -10.109 & -1.198 & $0.0000^{* *}$ \\
\hline \multirow{4}{*}{ (3) } & $G_{t}$ & -5.110 & -4.241 & 0.0000 * \\
\hline & $G_{a}$ & -6.109 & 3.110 & 0.0005 * \\
\hline & $P_{t}$ & -7.665 & -3.113 & $0.0002^{* *}$ \\
\hline & $P_{a}$ & -5.009 & -4.864 & 0.0000 * \\
\hline \multirow{4}{*}{ (4) } & $G_{t}$ & -9.011 & -3.196 & $0.0000^{* *}$ \\
\hline & $G_{a}$ & -7.102 & 4.009 & 0.0013 * \\
\hline & $P_{t}$ & -4.003 & 1.118 & 0.0001 * \\
\hline & $P_{a}$ & 3.009 & -3.152 & 0.0180 * \\
\hline
\end{tabular}

Note: ${ }^{*},{ }^{* *}$ at $1 \%$ and $5 \%$ level of significance, SIC is used for optimum lag criteria.

The evidence of cointegration among the regressors encouraged us to proceed with the long-run estimations. The robust CUP-FM and CUP-BC estimation techniques are used to investigate the long-run relationship among all three models. Table 6 confirms for model 1 that digitalization has a significant impact on the shadow economy's growth in the selected South Asian countries. The progress in fintech innovation such as the increase in ATM and mobile money transactions helps reduce the shadow economy. A 1\% increase in ATM and mobile money transactions helps in reducing the shadow economy by 0.081 and $0.092 \%$, respectively, since increased use of internet-based transactions and ATMs promotes financial inclusion, and financial inclusion has an inverse relationship with shadow economy growth. The findings are in line with the study of Ajide [51]. Hence, we can accept the null hypothesis (H1) based on the outcome, which concludes that digital finance creates negative pressure on the growth of the shadow economy.

The empirical results also collaborate with the theoretical background of technological spillover theory, which states that technological development through the squid effect helps in the dissemination of financial services to the unbanked population. In the case of control variables, the study concludes that economic growth, industrial productivity, and foreign direct investments help in reducing the shadow economy. On the other hand, unemployment increases the share of the shadow economy among the South Asian countries. Several studies focusing on the relationship between economic growth, unemployment, and shadow economy support the above finding, for instance, [23,52].

Furthermore, the empirical analysis investigating the relation between digitalization and financial stability concludes that digital finance has a significant impact on the financial sector instability of the selected South Asian countries. The result of model 2 confirms that ATMs and mobile money transactions have a significant and positive impact on NPLs. The increased use of digital finance increases the ratio of nonperforming loans to total loans. A 1\% rise in ATMs and mobile money transactions increases NPLs by 0.004 and $0.026 \%$, respectively. Increased usage of mobile money transactions and ATMs encourage the banks to use aggressive credit strategies. The use of aggressive credit policies increases the bank credit to deposit ratio, and through the mediation process, increases NPLs. A strand of literature also highlights that inadequacy in the security infrastructure of digital transactions among the emerging countries also promotes internet-based fraud and scams. These scams and fraudulent acts further aggravate the problem of financial sector instability. The above findings are in line with the studies of Ozili [12] and Risman et al. [8]. Thus, based on the above outcome, we can reject the $\mathrm{H} 2$, and conclude that digital finance has a negative impact on the financial stability of emerging countries. 
Table 6. CUP-FM and CUP-BC results.

\begin{tabular}{|c|c|c|c|c|}
\hline \multirow{2}{*}{$\begin{array}{c}\text { Variables } \\
\text { Model 1: Dependent Variable Ln SE }\end{array}$} & \multicolumn{2}{|c|}{ CUP-FM } & \multicolumn{2}{|c|}{ CUP-BC } \\
\hline & Coefficient & $t$-Value & Coefficient & $t$-Value \\
\hline Ln MMT & $-0.092 *$ & -16.05 & $-0.031 *$ & -18.04 \\
\hline Ln ATM & $-0.081 *$ & -35.94 & $-0.042 *$ & -38.22 \\
\hline Ln GDP & $-0.039^{* *}$ & -14.65 & $-0.184^{* *}$ & -65.29 \\
\hline Ln IIP & $-0.091 *$ & -22.94 & $-0.118 *$ & -31.09 \\
\hline Ln FDI & $-0.020 *$ & -34.25 & $-0.009 *$ & -40.19 \\
\hline Ln Un & $0.095 *$ & 29.05 & 0.254 * & 29.22 \\
\hline \multicolumn{5}{|l|}{ Model 2: Dependent variable Ln NPL } \\
\hline Ln MMT & $0.026^{*}$ & 36.12 & $0.012 *$ & 31.03 \\
\hline Ln ATM & 0.004 * & 22.71 & 0.153 & 42.00 \\
\hline Ln GDP & $-0.084 *$ & -54.11 & $-0.080 * *$ & -15.30 \\
\hline Ln IIP & $-0.037^{* *}$ & -21.23 & $-0.210 *$ & -32.03 \\
\hline Ln FDI & $-0.081 *$ & 30.12 & $0.382 *$ & 33.18 \\
\hline Ln Un & $0.095 *$ & 20.19 & $0.321 * *$ & 23.98 \\
\hline \multicolumn{5}{|l|}{ Model 3: Dependent variable Ln BCDR } \\
\hline Ln MMT & $0.082 *$ & 23.09 & $0.051 *$ & 27.19 \\
\hline Ln ATM & $0.035 *$ & 34.12 & 0.080 * & 43.10 \\
\hline Ln GDP & $0.049 *$ & 32.19 & $0.041 *$ & 29.03 \\
\hline Ln IIP & $0.086^{* *}$ & 12.12 & $0.081 * *$ & 41.09 \\
\hline Ln FDI & $0.052 *$ & 11.13 & $0.223 *$ & 33.86 \\
\hline Ln Un & $0.052 *$ & 09.18 & 0.050 * & 28.13 \\
\hline
\end{tabular}

Note: ${ }^{*}, * * 1$ and $5 \%$ level of significance.

The empirical results of model 3 confirm that ATMs and mobile money transactions have a significant and positive impact on the bank credit and deposit ratio. A $1 \%$ increase in ATMs and mobile money transactions rises the bank credit to deposit ratio by 0.03 and $0.08 \%$, respectively. Previous studies have concluded that the excessive usage of ATMs and internet-based transactions increase the spending rate of individuals. Banks promote a loose credit policy to provide easy credit to individuals to meet their spending needs, and thus, due to digitalization, bank credit to deposit ratio increases [8]. Our empirical findings also conclude that industrial productivity, economic growth, and foreign direct investment assist in decreasing NPLs. However, unemployment increases NPLs. In addition, in terms of bank credit to deposit ratio, our empirical findings conclude that industrial productivity, economic growth, foreign direct investment, and unemployment increases bank credit to deposit percentage in the selected South Asian countries. Several studies support the above findings, for instance, [53,54]. Thus, based on the empirical analysis, we can conclude that digitalization helps in reducing shadow economy growth through financial inclusion, but promotes financial sector instability in the selected emerging countries.

\section{Conclusions and Policy Implications}

The advance in technological innovation has made a significant contribution towards the development of different sectors of the economy. The financial sector of the developed economies also benefits significantly from the fintech revolution, or digitalization. The fintech revolution has also increased the accessibility of financial services in the developed countries. The current study investigates the effect of digitalization of financial services on shadow economy growth and financial sector instability among the selected South Asian emerging countries. To achieve the above objective, first we have empirically tested the 
presence of cross-sectional dependence among the sample data by employing the Breusch Pagan and Pesaran LM tests. After confirming the issue of CD, we have used the second generation CIPS, and CADF unit root test, as these tests provide robust estimates. Further, after checking the unit root, we have examined the long-run cointegration between the independent and dependent variables. Finally, after confirming the evidence of long-run cointegration, we have investigated the long-run relationship among all the models by using the reliable and robust CUP-FM and CUP-BC estimation technique.

Our empirical analysis concludes that digitalization assists in reducing the shadow economy percentage of GDP. Digitalization depicted by the proxy of ATMs per 100,000 population and mobile money transactions has significantly lowered the base of the shadow economy among the selected South Asian countries. Fintech innovation helps in the development of banking infrastructure, and the efforts to increase the financial outreach by emerging countries like India and Pakistan further enhance financial inclusion. Therefore, based on these combined efforts of fintech innovation and financial sector outreach activities, the shadow economy shows a downward trend among the sample South Asian countries.

In terms of financial stability, our empirical investigation concludes that excessive use of mobile money transactions and ATMs among emerging countries promotes financial sector instability by increasing the percentage of NPLs and bank credit to deposit ratio. The increased use of mobile and internet-based transactions increases the spending rate of individuals. To meet the spending requirement, individuals resort to banking credit facilities. This excessive credit availability puts pressure on the portfolio of NPLs in emerging countries $[55,56]$. However, on the positive side, the impact of digitalization on financial sector instability is sparse as other determinants contribute excessively towards financial sector instability. Previous studies also conclude that, in the long run, fintech innovation helps in providing a more secure banking and financial sector environment, which we can infer from the data of developed countries [1]. Better and improved technological infrastructure helps in controlling financial fraud to an extent. Thus, based on these facts, we can infer that, although digitalization promotes financial sector instability initially, in the long-run we can assume a more stable financial sector environment based on improvement in fintech innovations and technologies among the emerging countries. Furthermore, among the control variables, our study concludes that foreign direct investment, industrial productivity, and economic growth help in controlling the growth of the shadow economy and NPLs among the emerging sampled countries. On the contrary, unemployment is a prominent issue among the sampled countries, which increases NPLs and the growth of the shadow economy.

The findings provide several implications for banking regulation and fintech innovation. First, policymakers should encourage more digitalization of banking services in emerging countries. Emerging countries require adequate resources and income to compete with the developed countries, and digitalization helps in availing those resources through inclusive growth and reduction in the informal economy. Second, emerging countries should invest more in creating a secure and stable digital infrastructure, as unstable and risky digital platforms promote the chances of financial risk and fraud. Policymakers should also consider reducing NPLs through fintech innovations. An adequate regulatory and supervisory framework is required to track NPLs and financial risk. Policymakers should encourage welfare-oriented digital banking services for individuals, businesses, and households. The government should also provide some financial assistance or subsidies to individuals and banking institutions to promote digital transactions.

Likewise, government should also ensure lower regulation for the fintech service providers so that they can improve their financial technology and intermediation function while reducing cost, where possible, to serve customers better. In addition, policymakers should also consider the cost involved in supplying fintech services to individuals, businesses, and households for the maintenance of adequate budgetary provisions. 
The study entails the following strength: this is the first study that evaluates the influence of digital finance on the shadow economy and financial instability in South Asian countries which, as per the author's knowledge, is not discussed in previous studies. Second, the current study also offers several policy recommendations from the context of emerging countries, which will be helpful in understanding the relevance of digital finance in emerging countries in the context of financial inclusion and stability.

\section{Limitations and Future Directions}

The study also has a few limitations. First, this study has only included two proxies for measuring digital finance. Future researchers can incorporate more variables to measure the digitalization of financial services. Second, due to lack of data availability, only three South Asian countries are included in the study, and thus future researchers can add other countries or blocs. Furthermore, future research can also incorporate other determinants to measure the financial sector instability associated with the digitalization of financial services.

Author Contributions: Conceptualization, M.A.K. and A.A.S.; methodology, A.A.S. and F.A.; formal analysis, F.A. and M.A.K.; investigation, F.A. and A.A.S.; data curation, J.E.T.S.; writing-original draft preparation, A.A.S. and M.A.K.; writing - review and editing, F.A. and J.E.T.S., funding, J.E.T.S. and F.A. All authors have read and agreed to the published version of the manuscript.

Funding: This research was funded by Ministerio Español de Ciencia, Innovacióny Universidades and FEDER grant number PGC2018-101555-B-I00 and UAL/CECEU/FEDER grant number UAL18FQM-B038-A.

Institutional Review Board Statement: Not applicable.

Informed Consent Statement: Not applicable.

Data Availability Statement: The data used in this study can be provided by the corresponding author on reasonable request.

Conflicts of Interest: The authors declare no conflict of interest.

\section{References}

1. Ozili, P.K. Digital Finance, Green Finance and Social Finance: Is There a Link? Finance Internet Q. 2021, 17, 1-7. [CrossRef]

2. Kshetri, N.; Loukoianova, E. Blockchain adoption in supply chain networks in Asia. IT Prof. 2019, 21, 11-15. [CrossRef]

3. Agur, I.; Peria, S.M.; Rochon, C. Digital financial services and the pandemic: Opportunities and risks for emerging and developing economies. Int. Monet. Fund Spec. Ser. COVID-19 Trans. 2020, 1, 1-13.

4. Ferrata, L. Digital financial inclusion-An engine for "leaving no one behind". Public Sect. Econ. 2019, 43, 445-458. [CrossRef]

5. Kim, D.-W.; Yu, J.-S.; Hassan, M.K. Financial Inclusion and Economic Growth in OIC countries. Res. Int. Bus. Financ. 2018, 43, 1-14. [CrossRef]

6. Medina, L.; Schneider, M.F. Shadow Economies around the World: What Did We Learn over the Last 20 Years? International Monetary Fund: Washington, DC, USA, 2018.

7. Mugoda, S.; Esaku, S.; Nakimu, R.K.; Bbaale, E. The portrait of Uganda's informal sector: What main obstacles do the sector face? Cogent Econ. Finance 2020, 8, 1. [CrossRef]

8. Risman, A.; Mulyana, B.; Silvatika, B.A.; Sulaeman, A.S. The effect of digital finance on financial stability. Manag. Sci. Lett. 2021, 11, 1979-1984. [CrossRef]

9. Mani, M. Financial inclusion in South Asia-Relative standing, challenges and initiatives. South Asian Surv. 2016, 23, 158-179. [CrossRef]

10. Wang, X.; He, G. Digital financial inclusion and farmers' vulnerability to poverty: Evidence from rural China. Sustainability 2020, 12, 1668. [CrossRef]

11. World Bank Group. World Development Report 2016: Digital Dividends; World Bank Publication: Washington, DC, USA, 2016.

12. Ozili, P.K. Impact of digital finance on financial inclusion and stability. Borsa Istanb. Rev. 2018, 18, 329-340. [CrossRef]

13. Afzal, M.H.B. Sustainable development of rural communities in Bangladesh by integrating mobile internet and agent banking technology. In Leadership, Innovation and Entrepreneurship as Driving Forces of the Global Economy; Springer: Cham, Switzerland, 2017; pp. 361-370.

14. Sapovadia, V. Financial inclusion, digital currency, and mobile technology. In Handbook of Blockchain, Digital Finance, and Inclusion, Volume 2; Academic Press: Cambridge, MA, USA, 2018; pp. 361-385.

15. Srivastava, A. The status and impact of E-finance on developing economy. Gold. Res. Thoughts 2014, 3, 1-7. 
16. Scott, B.; Loonam, J.; Kumar, V. Exploring the rise of blockchain technology: Towards distributed collaborative organizations. Strat. Chang. 2017, 26, 423-428. [CrossRef]

17. Evans, O. Connecting the poor: The internet, mobile phones and financial inclusion in Africa. Digit. Policy Regul. Gov. 2018, 20, 568-581. [CrossRef]

18. Niebel, T. ICT and economic growth-Comparing developing, emerging and developed countries. World Dev. 2018, 104, 197-211. [CrossRef]

19. Karakara, A.A.W.; Osabuohien, E. ICT adoption, competition and innovation of informal firms in West Africa: A comparative study of Ghana and Nigeria. J. Enterp. Commun. People Places Glob. Econ. 2020, 14, 397-414. [CrossRef]

20. Ramli, F.A.A.; Hamzah, M.I. Mobile payment and e-wallet adoption in emerging economies: A systematic literature review. J. Emerg. Econ. Islam. Res. 2021, 9, 1-39. [CrossRef]

21. Goldfarb, A.; Tucker, C. Digital economics. J. Econ. Lit. 2019, 57, 3-43. [CrossRef]

22. Arvin, M.B.; Pradhan, R.P.; Nair, M.S. Are there links between institutional quality, government expenditure, tax revenue and economic growth? Evidence from low-income and lower middle-income countries. Econ. Anal. Policy 2021, 70, 468-489. [CrossRef]

23. Schneider, F.; Bajada, C. An international comparison of underground economic activity. In Size, Causes and Consequences of the Underground Economy; Routledge: London, UK, 2018; pp. 73-106.

24. Dreher, A.; Schneider, F. Corruption and the shadow economy: An empirical analysis. Public Choice 2010, 144, 215-238. [CrossRef]

25. Schneider, F.; Hametner, B. The shadow economy in Colombia: Size and effects on economic growth. Peace Econ. Peace Sci. Public Policy 2014, 20, 293-325. [CrossRef]

26. Habibullah, M.S.; Din, B.; Saari, M.Y.; Baharom, A.H. Shadow economy and financial sector development in Malaysia. Int. J. Econ. Financ. Issues 2016, 6, 181-185.

27. Ban, C.; Gabor, D. The political economy of shadow banking. Rev. Int. Politi-Econ. 2016, 23, 901-914. [CrossRef]

28. Zhou, S.; Tewari, D.D. Shadow banking, risk-taking and monetary policy in emerging economies: A panel cointegration approach Cogent Econ. Financ. 2019, 7, 1636508. [CrossRef]

29. Elsherif, N. Financial Inclusion, Shadow Economy and 8nancial Stability: Evidence from Emerging Economies. Master's Thesis, The American University in Cairo, Cairo, Egypt, 2019. AUC Knowledge Fountain. Available online: https://fount.aucegypt.edu/ etds/520 (accessed on 16 July 2021).

30. Elgin, C.; Uras, B.R. Public debt, sovereign default risk and shadow economy. J. Financ. Stab. 2013, 9, 628-640. [CrossRef]

31. Adrian, T. Assessing Global Financial Stability. Cato J. 2019, 39, 339.

32. Mörttinen, L.M.; Poloni, P.; Sandars, P.; Vesala, J.M. Analysing banking sector conditions: How to use macro-prudential indicators. ECB Occas. Pap. 2005, 26. [CrossRef]

33. Hodula, M.; Pfeifer, L. Fiscal-monetary-financial stability interactions in a data-rich environment. Rev. Econ. Perspect. 2018, 18, 195-224. [CrossRef]

34. Vives, X. Digital disruption in banking. Annu. Rev. Financ. Econ. 2019, 11, 243-272. [CrossRef]

35. Ketterer, J.A. Digital Finance: New times, New Challenges, New Opportunities; IDB-Inter American Development Bank: Washington, DC, USA, 2017.

36. García, M.J.R.; José, M. Can financial inclusion and financial stability go hand in hand. Econ. Issues 2016, 21, 81-103.

37. Khan, H.R. Financial inclusion \& payment systems: Recent trends, current challenges and emerging issues. In Speech by Deputy Governor, Reserve Bank of India Monthly bulletin, New Delhi, India; RBI: New Delhi, India, 2012; Volume 13.

38. Pazarbasioglu, C.; Mora, A.G.; Uttamchandani, M.; Natarajan, H.; Feyen, E.; Saal, M. Digital Financial Services; World Bank: Washington, DC, USA, 2020.

39. Pazarbasioglu, C.; Mora, A.G. Expanding Digital Financial Services Can Help Developing Economies Cope with Crisis Now and Boost Growth Later; World BankVoices (Blog): Washington, DC, USA, 2020.

40. Morgan, P.; Pontines, V. Financial Stability and Financial Inclusion, ADBI Working Paper 488, Tokyo. 2014. Available online: https:/ / www.adb.org/sites/default/files/publication/156343/adbi-wp488.pdf (accessed on 22 November 2021).

41. Hannig, A.; Jansen, S. Financial Inclusion and Financial Stability: Current Policy Issues. 2010. Available online: https://www. econstor.eu/bitstream/10419/53699/1/654899762.pdf (accessed on 22 November 2021).

42. Siddik, M.N.A.; Kabiraj, S. Digital finance for financial inclusion and inclusive growth. In Digital Transformation in Business and Society; Palgrave Macmillan: Cham, Switzerland, 2020; pp. 155-168.

43. Saha, M.; Dutta, K.D. Nexus of financial inclusion, competition, concentration and financial stability: Cross-country empirical evidence. Compet. Rev. Int. Bus. J. 2020. [CrossRef]

44. Nathaniel, S.; Anyanwu, O.; Shah, M. Renewable energy, urbanization, and ecological footprint in the Middle East and North Africa region. Environ. Sci. Pollut. Res. 2020, 27, 14601-14613. [CrossRef] [PubMed]

45. Westerlund, J. Testing for error correction in panel data. Oxf. Bull. Econ. Stat. 2007, 69, 709-748. [CrossRef]

46. Ahmed, Z.; Le, H.P. Linking Information Communication Technology, trade globalization index, and $\mathrm{CO}_{2}$ emissions: Evidence from advanced panel techniques. Environ. Sci. Pollut. Res. 2021, 28, 8770-8781. [CrossRef] [PubMed]

47. Ahmed, Z.; Ali, S.; Saud, S.; Shahzad, S.J.H. Transport $\mathrm{CO}_{2}$ emissions, drivers, and mitigation: An empirical investigation in India. Air Qual. Atmos. Health 2020. [CrossRef] 
48. Ahmed, Z.; Asghar, M.M.; Malik, M.N.; Nawaz, K. Moving towards a sustainable environment: The dynamic linkage between natural re- sources, human capital, urbanization, economic growth, and ecological footprint in China. Res. Policy 2020, 67, 101677. [CrossRef]

49. Ahmed, Z.; Zafar, M.W.; Ali, S.; Danish. Linking urbanization, human capital, and the ecological footprint in G7 countries: An empirical analysis. Sustain. Cities Soc. 2020, 55, 102064. [CrossRef]

50. Bai, J.; Kao, C.; Ng, S. Panel cointegration with global stochastic trends. J. Econ. 2009, 149, 82-99. [CrossRef]

51. Ajide, F.M. Shadow economy in Africa: How relevant is financial inclusion? J. Financ. Regul. Compliance 2021, 29, 297-316. [CrossRef]

52. Sahnoun, M.; Abdennadher, C. The Nexus between Unemployment Rate and Shadow Economy: A Comparative Analysis of Developed and Developing Countries Using a Simultaneous-Equation Model; No. 2019-30; Economics Discussion Papers, Kiel Institute for the World Economy (IfW): Kiel, Germany, 2019.

53. Banna, H.; Alam, M.R. Impact of digital financial inclusion on ASEAN banking stability: Implications for the post-Covid-19 era. Stud. Econ. Financ. 2021, 38, 504-523. [CrossRef]

54. Ahmed, F.; Syed, A.A.; Kamal, M.A.; de las Nieves López-García, M.; Ramos-Requena, J.P.; Gupta, S. Assessing the Impact of COVID-19 Pandemic on the Stock and Commod ity Markets Performance and Sustainability: A Comparative Analysis of South Asian Countries. Sustainability 2021, 13, 5669. [CrossRef]

55. Syed, A.A.; Tripathi, R. Non-performing loans in BRICS nations: Determinants and macroeconomic impact. Indian J. Finance 2019, 13, 22-35. [CrossRef]

56. Syed, A.A.; Aidyngul, Y. Macro economical and bank-specific vulnerabilities of nonperforming loans: A comparative analysis of developed and developing countries. J. Public Affairs 2020, e2414. [CrossRef] 